\title{
APPLICATION OF THE INQUIRY MODEL ON SCIENCE LEARNING OF VIBRATION AND WAVES
}

\author{
Tati Sudaryani \\ SMP Negeri 5 Sungai Raya, Kubu Raya Regency \\ Email:trisnotati13@gmail.com
}

\begin{abstract}
This study aims to obtain an increase in the learning activities of class VIII A students of SMP Negeri 5 Sungai Raya in the 2018/2019 academic year. Student learning activities in science learning material Vibration and Waves using the Inquiry Model in class VIII A SMP Negeri 5 Sungai Raya have increased every cycle, it can be seen from the level of student learning completeness per cycle, namely in cycle 1 based on the results of the pre test, the score is obtained the highest is 86.6 and the lowest value obtained is 46.6. The average pre-test value of the experimental class was 68.23. Meanwhile, based on the results of the post test, the highest score was 93.3 and the lowest score was 66.6. The average post-test score for the experimental class was 82.03. Then in cycle 2 based on the results of the pre test, the highest score was 100 and the lowest score was 53.3. The average value of the experimental class pre test is 77.21. Based on the results of the post test, the highest score was 100 and the lowest score was 86.6. The average post-test score for the experimental class was 97.92. There is a very significant change in the increase in student learning activities between the pre-test and post-test. Based on the Minimum Completeness Criteria (KKM) the percentage of students has increased.
\end{abstract}

\section{Keywords: Inquiry Model, Student Learning Activities}

\section{INTRODUCTION}

Learning in this current era does not only require "Transfer of Knowledge" i.e. a teacher only transfers the knowledge he has to his students, but learning in this current era also requires teachers to "transfer of value" namely forming character, behavior or morals. students to do better. In this case, a teacher is required not only to pursue and prioritize the cognitive development of the participants, but also to pay attention to the development of the affective and psychomotor aspects of the students.

Basically, the development of a child is to develop a correct understanding of how the world works, learn the "rules of the game" all aspects of this world. Children will grow up to be individuals with character when they grow up in an environment of character.

curriculum implementation through the inquiry model, it is hoped that it can help students understand the lessons that will be delivered by the teacher. As according to Rusyan (1994, pp. 23-24) that the learning readiness factor will make learning activities easier and more successful. This readiness factor is closely related to the problem of maturity, interests, needs, and developmental tasks.

Science education has a goal to improve the competence of students in order to meet the needs of life in various situations. Learning science, including physics, aims to master scientific concepts that are applicable and meaningful for students through inquirybased science learning activities. Inquirybased learning will train the development of students' science process skills, thus enabling students to find their own concepts that can be understood in science. 
Natural Sciences or Natural Sciences cannot be separated from technological advances that are increasingly developing because by having a good understanding of concepts and skills in the field of physics, human resources in utilizing and processing technology are increasingly advanced. Learning physics that intersects with nature and its surroundings makes humans not only easy to carry out activities but can also foster a strong belief in the greatness of the creator. Education has a mission to produce humans who not only take advantage of natural supplies, but also humans who want to be grateful to those who made humans and nature, treat humans as caliphs and treat nature not only as objects of suffering, but also as components of the living system.

From the background of the problem above, the writer hopes that the implementation of the 2013 curriculum through the inquiry model can improve student learning activities. Vibration and Wave materials can be useful lessons for the continuation of a successful teaching and learning process, and create the excellent generation that we hope for.

Learning is an effort to teach students. Learning is a process organized by teachers to teach students how to acquire and process knowledge, skills and attitudes. Learning activities occur educative interactions between two parties, namely students who carry out learning activities with educators who carry out learning activities, where there is also a process of selecting, determining, developing appropriate methods so that learning objectives can be achieved. Effective learning according to Sutikno (2005, p.45) is a learning that allows students to learn easily, fun and achieve learning objectives as expected.

The definition of learning according to Crow and Crow $(1979$, p.87) in their book Educational Psychology states that learning is an active process that needs to be stimulated and guided toward desirable outcomes. (Learning is an active process that requires stimulation and guidance to produce the expected results). Basically, learning is an interaction between teachers and students, so that there is a change in behavior for the better.

Science learning is an interaction process carried out by teachers and students in assessing the mastery of a collection of knowledge in the form of facts, concepts, or principles and a process of discovery.

The teaching and learning process is a complex phenomenon. Everything means every word, thought, action, and association the extent to which you can change the environment, presentation, and teaching design, to the extent that the learning process takes place (Lozanov, 1978, in De Porter, 2000, p.3)

In Permendikbud Number 22 of 2016 it is said that inquiry learning is referred to together with discovery. In Webster's Collegiate Dictionary inquiry is defined as "asking about" or "looking for information". Discovery is referred to as "the act of finding". So, this learning has two main processes. First, involving students in asking or formulating questions (to inquire), and second, students uncovering, finding (to discover) answers to their questions through a series of investigation activities and similar activities (Silberman, 2013, p.10).

According to Sanjaya (2011, p. 196), the inquiry learning model is a series of learning activities that emphasize critical and analytical thinking processes to seek and find answers to the problems in question. The inquiry learning model involves students in answering the teacher's questions. Students conduct investigations, while the teacher guides them in the right direction. According to Hamalik (2001, p.8), in this learning model, teachers need to have the skills to provide guidance, namely diagnosing students' difficulties and providing assistance in solving the problems they face.

Inquiry/discovery is a learning process based on search and discovery through a systematic thinking process. Knowledge is not just a collection of facts resulting from remembering, but the result of the process of finding or constructing. In other words, learning is a process of facilitating 
discovery activities (inquiry) so that students acquire knowledge and skills through their own discovery (discovery).

The first objective of Inquiry/Discovery Learning is for students to be able to formulate and answer the questions of what, who, when, where, how, why, and so on. In other words, Inquiry/Discovery Learning aims to help students think analytically. The second goal is to encourage students to be more daring and creative in imagining. With imagination, students are guided to create something using the knowledge they have gained. This discovery can be in the form of improvement or refinement of what already exists, or creating ideas, ideas, or tools that do not yet exist (Anam, 2015:9).

The process of collecting data, observing, and summarizing information, especially numerical data in Inquiry/Discovery Learning, is effective in stimulating discussion to develop the desired critical thinking skills. Students need to experience how to draw scientific conclusions based on observations of facts and a collection of data obtained.

Effective learning is learning that provides opportunities for self-study or doing activities alone. The learning process carried out in the classroom is an activity to transform knowledge, attitudes, and skills (Yamin, 2007, p.75). Activity is a very important principle or principle in teaching and learning interactions (Sardiman, 2006, p. 96).

Learning activities can be realized if students are actively involved in learning. Yamin (2007, p. 82) defines active learning as a human effort to build knowledge within himself. Learning will result in a change and improvement in the abilities, knowledge and skills of students. Students are able to explore

\section{FINDINGS AND DISCUSSION}

In this first cycle classroom action research, the researcher refers to the improvement of students' learning activities with the Inquiry Model. In cycle 1, the researcher will apply the Inquiry Model. Observations are carried out by researchers in their abilities with their curiosity so that the interactions that occur will become experiences and the desire to know something new.

Based on the above opinion, it can be concluded that learning activities are physical and mental activities or actions carried out by individuals to build knowledge and skills in learning activities. Learning activities will make learning effective. Teachers do not only convey knowledge and skills. However, teachers must be able to bring students to be active in learning.

\section{RESEARCH METHODOLOGY}

In this study, the subjects who carried out the action were researchers as science teachers and the subjects who received the action were students of class VIII A of SMP Negeri 5 Sungai Raya as many as 29 students. 1. Classroom Action research was conducted on Class VIII A students of SMP Negeri 5 Sungai Raya in the 2018-2019 academic year, with a total of 29 students. The action is carried out in 2 cycles. The activity is carried out in the even semester of the 20182019 school year. The research was carried out from January 9 to March 18 2019. In implementing the action, the design was carried out in 2 cycles which included; (a) planning, (2) action, (3) observation, (4) reflection.

Sources of data in this study came from two sources, namely; students obtained data about increasing student learning activities and teachers obtained data about the application of inquiry learning. In data collection the technique used is to use observation and tests. The indicator of success in this study is if students in class VIII A of SMP Negeri 5 Sungai Raya get a score according to the KKM standard value of 70 . collaboration with colleagues (Mrs. Indarti, S.Pd). Colleagues function as observers in each implementation of the cycle. The results of the observer will be discussed with the researcher. The results of the merger will be used as observations. The researcher's observations were related to student activities, student interaction, student activity, drama 
implementation, and all the facts that occurred during the learning process.

In the recapitulation of student learning activities in cycle 1 , the data obtained showed that the learning effectiveness of students, amounting to 29 people in cycle 1 , based on the results of the pre-test, the highest score was 86.6 and the lowest score was 46.6. The average pre-test value of the experimental class was 68.23. Meanwhile, based on the results of the post test, the highest score was 93.3 and the lowest score was 66.6. The average post-test score for the experimental class was 82.03 . There is a change, namely an increase in learning activities between pre-test and post-test.

Then based on the data obtained from the completeness of Cycle 1 learning activities, it can be seen that the results of the pre-test there are 13 students who have reached the KKM limit. Meanwhile, there are 16 other students who have not met the KKM score limit. Then on the completion of the post-test learning activities, it can be seen that there are 2 students who have not reached the KKM limit. Meanwhile, 27 other students or 93\% of the sample population have reached the KKM limit. The learning activities of students in the first cycle are then evaluated and reflected on the learning implementation process in order to achieve the KKM limit target in cycle 2 .

These results indicate that in the first cycle classically, students have not finished studying, because the desired completeness is 70 according to the KKM value. This is because students still feel new and do not understand what the teacher means and uses by using the inquiry learning model. The implementation of teaching and learning activities for cycle 2 was carried out on February 11, 2019 at SMP Negeri 5 Sungai Raya for the 2018-2019 school year. In this case the researcher acts as a teacher. The teaching and learning process refers to the lesson plan by paying attention to revisions in cycle 1 , so that mistakes or deficiencies in cycle 1 do not occur again in cycle 2 . Observations are carried out simultaneously with the implementation of teaching and learning.

At the end of the teaching and learning process, students are given formative tests 2 with the aim of knowing the level of success of students in the teaching and learning process that has been carried out. The instrument used is formative test 2 , which is a recapitulation of student learning activities through a series of tests, namely pre-test and post-test. Student learning activities in the recapitulation of student learning activities in cycle 2 showed that the effectiveness of student learning in cycle 2 based on the results of the pre-test obtained the highest score of 100 and the lowest score obtained was 53.3. The average value of the experimental class pre test is 77.21. Based on the results of the post test, the highest score was 100 and the lowest score was 86.6. The average post-test score for the experimental class was 97.92. There is a very significant change in the increase in student learning activities between the pre-test and post-test. Based on the Minimum Completeness Criteria (KKM) the percentage of students has increased, more complete information can be seen in the completeness of Cycle 2 learning activities. students have not completed reaching the KKM limit. Then after the implementation of learning, it can be seen that there is an increase in overall student learning activities when compared to the previous cycle 1 . In the completeness of post-test learning activities, it can be seen that $100 \%$ of the total sample population has completely met the KKM standards.

The results in cycle 2 have improved better than cycle 1 . The increase in learning activities in cycle 2 is influenced by an increase in the ability of teachers to apply Inquiry Model Learning, so that students become more accustomed to learning like this so that students are easier to understand. material that has been given. In addition, this completeness is also influenced by the cooperation of students who have mastered the subject matter to teach their friends who have not mastered it. 
Based on the results of the research above, the students' learning activities for science lessons by applying the Inquiry Model have very good results. This can be seen in every meeting of 29 students at the time this research was conducted by showing that the learning effectiveness of 29 students in cycle 1 based on the results of the pre-test obtained the highest score of 86.6 and the lowest score obtained was 46.6 . The average pre-test value of the experimental class was 68.23. Meanwhile, based on the results of the post test, the highest score was 93.3 and the lowest score was 66.6. The average post-test score for the experimental class was 82.03. There is a change, namely an increase in learning activities between pre-test and post-test.

While the learning activities of students in cycle 2 showed that the effectiveness of student learning based on the results of the pre-test obtained the highest score of 100 and the lowest score obtained was 53.3. The average value of the experimental class pre test is 77.21. Based on the results of the post test, the highest score was 100 and the lowest score was 86.6. The average post-test score for the experimental class was 97.92 . There is a very significant change in the increase in student learning activities between the pre-test and post-test. Based on the Minimum Completeness Criteria (KKM) the percentage of students has increased,

Based on the 2013 Curriculum, students are said to be complete if they have achieved the KKM standard score of 70 . Meanwhile, in this study, the achievement of a score of 70 in (cycle 2) has been achieved according to the target set in the 2013 Curriculum. Thus, the proposed hypothesis can be accepted. .

\section{CONCLUSION AND SUGGESTION}

From the results of the research in the previous chapter, it can be concluded that the application of the Inquiry model to the science learning of Vibration and Wave material in class VIII A is: 1. Formulating the problem questions, or topics to be investigated. 2. Planning procedures or steps for data collection and analysis. 3. Collect and analyze data. Activities to collect information, facts, and data, followed by analyzing activities. 4. Draw conclusions Draw conclusions (answers or brief explanations) 5 . Application and Follow-up Apply the results and explore further questions or problems to find answers.

Student learning activities in science learning material Vibration and Waves using the Inquiry Model model in class VIII A SMP Negeri 5 Sungai Raya have increased every cycle, this can be seen from the level of student learning mastery per cycle, namely in cycle 1 based on the pre test results obtained the highest score was 86.6 and the lowest score obtained was 46.6. The average pre-test value of the experimental class was 68.23. Meanwhile, based on the results of the post test, the highest score was 93.3 and the lowest score was 66.6. The average post-test score for the experimental class was 82.03. Then in cycle 2 based on the results of the pre test, the highest score was 100 and the lowest score was 53.3. The average value of the experimental class pre test is 77.21. Based on the results of the post test, the highest score was 100 and the lowest score was 86.6. The average post-test score for the experimental class was 97.92 . There is a very significant change in the increase in student learning activities between the pre-test and post-test. Based on the Minimum Completeness Criteria (KKM) the percentage of students has increased.

From the research results obtained from the previous description so that the teaching and learning process in junior high schools (SMP) is more effective and provides optimal results for students, the following suggestions are submitted: 1. To implement the Inquiry Model requires sufficient preparation, so that the teacher must be able to determine or choose a topic that can really be applied with the Inquiry Model to obtain optimal results. $2 . \quad$ In order to improve student learning outcomes, teachers should train students more often with discovery activities, even at a simple level, where students will be able to discover new 
knowledge, acquire concepts and skills, so that students succeed or are able to solve problems. which he faced.

\section{REFERENCES}

Crow, L. D., \& Crow, A. (1979). Educational Psychology, New York: American Book Compan.

DePorter, B, Reardon, M., \& Singer, SNourie. (2010). Ed. 2, cet. to -1 Quantum Teaching. Translator: Ary Nilandari. Bandung: Kaifa.

Hamalik, O. (2001). Proses Belajar Mengajar. Jakarta: Bumi Aksara.

Peraturan Menteri Pendidikan Nasional No 22 Tahun 2006 tentang Standar Kompetensi dan Kompetensi Dasar Sekolah Menengah Pertama SMP/Madrasah Tsanawiyah MTs.
Rusyan, A.T. dkk. (1994). Pendekatan dalam Proses Belajar Mengajar. Bandung: Remaja Rosdakarya.

Sardiman, A.M. (2006). Penelitian Tindakan Kelas. Jakarta: Bumi Aksara.

Silberman, M. (2013). Pembelajaran Aktif 101 Strategi Untuk Mengajar Secara Aktif. Jakarta: Permata Puri Media.

Sutikno, M. S. (2005) Pembelajaran Efektif: Apa dan Bagaimana Mengupayakannya?, Mataram: NTP Press .

Yamin, M. (2007). Profesionalisasi Guru \& Implementasi KTSP. Jakarta: Gaung. Persada Press. 